\title{
POLA INTERAKSI PERS, PEMERINTAH DAN MASYARAKAT DALAM MEMBENTUK SISTEM PERS PANCASILA:Suatu Analisis Retrospektif
}

\author{
Abd. Rasid \\ Dosen Fakultas Dakwah dan Komunikasi \\ UIN Sunan Gunung Djati Bandung \\ E-mail: Arasid_32@yahoo.com
}

\begin{abstract}
ABSTRAK. Pers Indonesia adalah pers Pancasila dalam artian pers yang berorientasi pada sikap dan tingkah laku yang berdasarkan nilai-nilai Pancasila dan UUD 1945. Hakekat pers Pancasila adalah pers yang sehat, yakni pers yang bebas dan bertanggung jawab, dalam menjalankan fungsinya sebagai penyebar informasi yang benar dan objektif, penyalur aspirasi rakyat dan kontrol sosial yang konstruktif. Melalui hakekat dan fungsi itu pers Pancasila mengembangkan suasana saling percaya menuju masyarakat terbuka yang demokratis dan bertanggung jawab. Dalam mengamalkan pers Pancasila mekanisme yang dipakai adalah interaksi positif antara Masyarakat, Pers dan Pemerintah. Hubungan antara pers dan pemerintah terjalin dalam suatu bentuk yang dijiwai oleh semangat persekawanan (partnership) dalam mengusahakan terwujudnya masyarakat yang adil dan makmur berdasarkan Pancasila.
\end{abstract}

Kata Kunci: Interaksi Pers, Pemerintah, Sistem Pers Pancasila

\section{INTERACTION OF PATTERN PRESS, GOVERNMENT AND SOCIETY, TO FORM PANCASILA PRESS SYSTEM}

\begin{abstract}
Indonesian press is the Pancasila press release in the sense-oriented attitudes and behavior based on the values of Pancasila and the 1945 Constitution. Essence Pancasila Press is a healthy, ie free press and responsible in carrying out its function as a disseminator of information is correct and objective, channeling people's aspirations and social control are constructive. Through the nature and function of the Pancasila Press develop an atmosphere of mutual trust towards an open society that is democratic and accountable. In practice the mechanisms used Pancasila Press is a positive interaction between people, the Press, and the Government. The relationship between press and government intertwined in a form that is animated by the spirit of partnership in seeking the establishment of a just and prosperous society based on Pancasila.
\end{abstract}

Keywords: Interaction of the Press, Government, Pancasila Press System. 


\section{PENDAHULUAN}

Pers Indonesia yang berkembang adalah pers pancasila yang berada pada posisi terdidik dan sekaligus mampu melaksanakan fungsi pendidik dengan sebaikbaiknya. Esensi pekerjaan media massa Indonesia sesungguhnya adalah innovator (pembaharu) kehidupan elite pers itu sendiri, masyarakat, dan pemerintahnya.

Kemajuan pers Indonesia, ditentukan oleh kemampuannya berperan sebagai penggerak dinamika kesadaran intelektual seluruh fungsi individual dan sosial di lingkungannya. Hanya media massa cetak dan elektronik yang mampu memberikan "nilai lebih" kejiwaan, terutama aspek intelektualnya, akan diterima oleh masyarakat dan pemerintahnya.

Pola akseptasi masyarakat dan pemerintah Indonesia terhadap pers nasional, pada akhirnya akan menentukan wajah pers kita yang sebenarnya. Apakah pers Indonesia sekedar merupakan sumber informasi pemerintah serta masyarakat yang majemuk, atau sekaligus juga sebagai sumber aspirasi pemerintah masyarakat. ${ }^{1}$

Posisi dan aspek-aspek ideal pers nasional kita itu, mendorong penampilan (performance) pers di negeri ini sebagai cermin dan alat ekspresi masyarakat serta pemerintah. Masyarakat memanfaatkan pers sebagai alat teropong terhadap kebijaksanaan dan tindakan pemerintah. Sebaliknya pemerintah mendayagunakan pers sebagai alat bantu lihat, dengar, dan rasa, dalam rangka menyesuaikan apaapa yang direncanakan serta dilaksanakan pemerintah dengan keinginan, kebutuhan, serta kepentingan masyarakatnya.

Pers Indonesia seharusnya dapat selalu tampil (eksis) sebagai salah satu sumber dan saluran dinamika masyarakat serta pemerintah. Posisi dan fungsi ideal pers nasional kita itu akan mendorong pola dan gaya ekspresif pers, secara bebas dan bertanggung jawab.

Pola dan gaya pemberitaan pers yang ekspresif menuntut kebergantungan antara pers dan pemerintah di sisi lain, dalam sifat kebergantungan yang disebut symbiose mutualistis (saling menguntungkan). Bukan yang hanya menguntungkan secara sepihak, tetapi merugikan pihak lain. Apalagi saling merugikan (symbiose parasitis).

Dalam rangka kebergantungan tersebut, maka pekerjaan pers Indonesia erat kaitannya dengan fungsi inovasi (pembaharu) dan dinamisasi kesadaran intelektual individu, baik di kalangan masyarakat awam, maupun di dalam birokrasi pemerintah. Konteks ini, mendorong pers nasional kita bertugas menyampaikan informasi yang dapat menumbuhkembangkan visi objektivitas publik terhadap kejadian, fakta, opini, dan sebagainya, yang diberitakan pers.

Kepribadian pers Indonesia akan sangat ditentukan oleh kemampuannya membuktikan keterdekatan fungsional dan profesionalnya dengan objektivitas

\footnotetext{
${ }^{1}$ Ali, Novel. 1999. Peradaban Komunikasi politik, Potret Manusia Indonesia. PT. Remaja Rosda Karya, Bandung, hal. 294
} 
pemberitaannya. Objektivitas pemberitaan ini, merupakan pondasi utama bagi citra pers nasional kita sepanjang zaman.

Objektivitas pemberitaan pers Indonesia itu pula yang membuat eksistensinya diakui sebagai lembaga sosial. Kedudukan pers nasional kita sebagai lembaga sosial tersebut, kemudian dipergunakan masyarakat dan pemerintah sebagai "cermin diri". Baik pemerintah maupun masyarakat. Biasanya akan melihat siapa, apa, dan bagaimana diri serta keberadaan mereka masing-masing, melalui pola dan gaya pemberitaan pers.

Dalam prakteknya, pers Indonesia tidak selamanya dapat berfungsi sebagai "cermin diri" secara faktual dan objektif. Karena pers nasional kita pada hakekatnya adalah pers yang bertanggung jawab, maka kebebasannya tidaklah bersifat mutlak. Akibatnya pers kita harus berupaya menyesuaikan diri dengan berbagai realitas di lingkungannya, agar dapat berfungsi sebagai "cermin" dimaksud.

Kebebasan pers Indonesia adalah kebebasan pers dalam kerangka kepentingan tanggung jawab tertantu yang tidak ditentukan oleh pers itu sendiri, tetapi juga ditentukan oleh masyarakatnya, dan terutama pemerintahnya. Ini mengakibatkan performance pers Indonesia sebagai pers bebas, tetapi harus selalu berorientasi pada pola-pola pertanggungjawaban menurut berbagai visi kepentingan.

Pers nasional kita memang free press (pers bebas). Namun kebebasan itu berada dalam kerangka kepentingan yang ditentukan bersama oleh pers yang bersangkutan, pemerintah serta mesyarakatnya. Kebebasan pers Indonesia, bukanlah kebebasan pers sebagaimana dalam sistem liberal. Kebebasan pers nasional kita, adalah kebebasan untuk memberitakan sesuatu, demi kepentingan pers itu sendiri, masyarakat dan pemerintahnya. Kebebasan pers kita ditandai pula oleh kesadaran profesionalnya untuk tidak memberitakan sesuatu, juga demi kepentingan tripartit tadi (pers, pemerintah, dan masyarakat).

Itu sebabnya, mengapa kebebasan pers Indonesia terkesan tidak mandiri. Pers Indonesia memang bukan pers yang mandiri. Kemandirian pers nasional kita, ditentukan oleh sejauhmana kemampuannya mengadopsi serta mengharmonisi berbagai kepentingan objektif, maupun kepentingan subjektif, baik yang berada pada pihak pers, pemerintah, maupun masyarakatnya. ${ }^{2}$

Di Indonesia pers di negara ini tidak menganut salah satu keempat sistem pers yang ada di dunia. Pers di Indonesia menganut sistem khas Indonesia, yakni pers Pancasila yang oleh Dewan Pers dalam sidangnya yang ke-25 didefinisikan sebagai "pers yang orientasi, sikap dan tingkah lakunya berdasarkan pada nilainilai Pancasila dan Undang-Undang Dasar 1945".

Istilah Pers Pancasila sudah dikemukakan oleh M. Wonohito, seorang wartawan senior kenamaan, jauh sebelum dicanangkan secara resmi oleh Dewan Pers dalam Sidang Pleno XXV di Surakarta pada tanggal 7-8 Desember 1984.

Setidak-tidaknya konsep Wonohito mengenai Pers Pancasila dapat diketahui dari diktat kuliah pada Sekolah Staf dan Komando ABRI Bagian gabungan, berjudul

\footnotetext{
${ }^{2}$ Ibid, hal. 296
} 
"Teknik Jurnalistik dalam Sistem Pers Pancasila" yang ia susun pada tanggal 2 Januari 1977.

Hakekat Pers Pancasila adalah Pers yang sehat, yakni Pers yang bebas dan bertanggung jawab dalam menjalankan fungsinya sebagai penyebar informasi yang benar dan objektif, penyalur aspirasi rakyat dan kontrol sosial yang konstruktif. $^{3}$ Melalui hakekat dan fungsi itu Pers Pancasila mengembangkan suasana saling percaya menuju masyarakat terbuka yang demokratis dan bertanggung jawab. Dalam mengamalkan Pers Pancasila mekanisme yang dipakai adalah interaksi positif antara Masyarakat, Pers dan Pemerintah. Dalam hal ini Dewan Pers berperan sebagai pengembang mekanisme positif terebut.

Terwujud tidaknya Pers Pancasila ditentukan oleh jurnalistik sebagai kegiatannya. Permasalahannya tidak dalam teknik pemberitaan, misalnya mengubah susunan kisah berita dari bentuk "piramida terbalik" juga tidak dalam penciptaan jenis "teras berita" (lead) atau "tata letak" (lay out) Khas Pers Pancasila. Kesemuanya itu hanyalah masalah teknik "pembangkitan perhatian" (attention arousing) agar khalayak tertarik untuk membeli dan membaca.

Pers Pancasila harus tercermin dalam isi beritanya. Adalah isi beritanya yang menunjukkan apakah berita itu disiarkan Pers Pancasila atau pers yang bersistem lain. Mungkin saja surat kabar atau majalah Indonesia dengan leluasa beroperasi berkat SIUPP yang telah berhasil menunjukkan hakekat Pers Pancasila sudah tentu ciri Pers Pancasila dalam pemberitaannya tidak selalu harus ditunjukkan secara eksplisit. Disinilah permasalahan jurnalistiknya. Suatu fakta atau opini dapat dituangkan dalam bentuk berita, tajuk rencana, pojok, artikel, foto, dan lain-lain. Karena tujuan wartawan sebagai komunikator, tidak hanya agar timbul efek kognitif pada para pembaca yang dijadikan sasarannya itu, mungkin pula efek afektif yang pada akhirnya diarahkan kepada timbulnya efek konatif, efek berbentuk kegiatan atau tindakan. Yang dipertanyakan ialah apakah pesannya (message-nya) merupakan salah satu dari butir-butir yang tercantum dalam Undang-undang tentang Ketentuan-ketentuan Pokok Pers.

Pers Pancasila tidak mungkin terlepas kaitannya dari Undang-Undang Republik Indonesia Nomor 21 Tahun 1982 Tentang Perubahan Atas Undang-Undang Nomor 11 Tahun 1966 Tentang Ketentuan-ketentuan Pokok Pers sebagaimana telah diubah dengan Undang-Undang Nomor 4 Tahun 1967. Pers Pancasila sebagai sistem Pers yang berlaku di Indonesia merupakan pengemban dan pelaksana butirbutir yang tercantum dalam Undang-undang tersebut. Di situ jelas dan tegas dinyatakan mengenai tugas, fungsi, hak, dan kewajiban pers, yakni dalam pasal 2 yang berbunyi sebagai berikut:

(1) Pers Nasional adalah alat Perjuangan Nasional dan merupakan mass media yang bersifat aktif, dinamis kreatif, edukatif informations dan mempunyai fungsi kemasyarakatan pendorong dan pemupuk daya pikir kritis dan progresif meliputi segala perwujudan kehidupan masyarakat Indonesia.

\footnotetext{
${ }^{3}$ Eyo Kahya, 2004. Perbandingan sistem dan Kemerdekaan Pers. Pustaka bani Quraisy, Bandung, hal. 117.
} 
(2) Pers Nasional bertugas dan berkewajiban:

a. melestarikan dan memasyarakatkan Pancasila sebagaimana termaktub dalam pembukaan Undang-Undang Dasar 1945 dengan Pedoman Penghayatan dan Pengamalan Pancasila.

b. memperjuangkan pelaksanaan amanat penderitaan rakyat berlandaskan Demokrasi Pancasila;

c. memperjuangkan kebenaran dan keadilan atas dasar kebebasan pers yang bertanggung jawab.

d. menggelorakan semangat pengabdian perjuangan bangsa, memperkokoh persatuan dan kesatuan nasional, mempertebal rasa tanggung jawab dan disiplin nasional, membantu serta menggairahkan partisipasi rakyat dalam pembangunan;

e. memperjuangkan terwujudnya tata Internasional baru di bidang Informasi dan Komunikasi atas dasar kepentingan Nasional dan percaya pada kekuatan diri sendiri dalammenjamin kerja sama Regional, antar regional dan internasional khususnya di bidang pers.

(3) Dalam rangka meningkatkan peranannya dalam pembangunan pers berfungsi sebagai pen yebar informasi yang objektif, menyalurkan aspirasi rakyat, meluaskan komunikasi dan partisipasi masyarakat serta melakukan kontrol sosial yang konstruktif. Dalam hal ini perlu dikembangkan interaksi positif antar pemerintah, pers dan masyarakat.

Jika diadakan perbandingan antara rumusan predikat Pers Pancasila dengan isi Pasal 2 Undang-Undang Nomor 21 Tahun 1982 dalam hal tahun pencanangan, sebenarnya undang-undang tersebut sudah terlebih dahulu; dan apabila benarbenar dilaksanakan, secara defakto pers nasional Indonesia sudah menganut sistem Pers Pancasila. Jika kemudian prediket Pers Pancasila dikumandangkan secara resmi oleh Dewan Pers, maksudnya tiada lain agar para insan Pers Indonesia lebih sadar akan tugas, fungsi, hak dan kewajibannya. Dengan demikian sesungguhnya tugas para wartawan dan karyawan pers beserta organisasinya, antara lain Persatuan Wartawan Indonesia, menjadi semakin berat karena akan dinilai oleh masyarakat.

Bagi para wartawan Indonesia yang telah memiliki Kode Etik wartawan sebagai pegangan dan pedoman pengabdiannya kepada negara dan masyarakat, pencanangan Pers Pancasila itu merupakan tantangan yang harus dijawab dengan karya jurnalistiknya yang bernilai luhur, lebih luhur daripada sistem pers asing. Juga bagi PWI menjadi tantangan untuk dijawab dengan membenahi diri lebih intensif, jangan sampai masih berlaku di masyarakat istilah-istilah ironis dan melakukan yang dilekatkan pada wartawan Indonesia, seperti: wartawan amplop, wargad (wartawan gadungan), WTS (Wartawan Tanpa Surat kabar), Muntaber (Muncul tanpa berita), dan lain-lain. ${ }^{4}$

${ }^{4}$ Effendy, Uchjana, Onong, 2003. I/mu, Teori \& Filsafat Komunikasi. PT. Citra Aditya Bakti, Bandung, hal. 115 


\section{SISTEM PERS INDONESIA}

Secara teoritis sistem pers yang dianut di Indonesia adalah sistem pers Tanggung Jawab Sosial. Pemikiran dasar teori ini sebagai berikut (Peterson, 1986:83), bahwa kebebasan, mengandung di dalamnya suatu tanggungjawab yang sepadan; dan pers, yang telah menikmati kedudukan terhormat dalam pemerintahan Amerika Serikat, harus bertanggungjawab kepada masyarakat dalam menjalankan fungsi-fungsi penting komunikasi massa dalam masyarakat modern. Asal saja pers tahu tanggung-jawabnya dan menjadikan itu landasan operasional mereka. Di Indonesia, landasan konstitusi yang dipakai adalah pasal 28 UUD 1945 yang berbunyi Kemerdekaan berserikat dan berkumpul, mengeluarkan pikiran dengan lisan dan tulisan dan sebagainya ditetapkan dengan undang-undang.

Dengan mengacu pada pasal tersebut, secara nyata kebebasan pers mendapat jaminan yang cukup kuat untuk melaksanakan fungsinya, yaitu (1) melayani sistem politik dengan menyediakan ruang diskusi bagi masyarakat untuk berdebat terutama dalam masalah kebijakan publik, (2) menjadi anjing penjaga dan hak-hak perorangan warga negara (control sosial), dan (3) membiaya finansial secara mandiri (Peterson, 1986:84).

Kontrol sosial yang dimaksud bahwa pers memposisikan sebagai kakuatan keempat (four estate) untuk mengontrol lembaga-lembaga politik lain yaitu eksekutif, yudikatif, dan legislatif dalam menjalankan fungsinya. Jika ada penyelewengan yang dilakukan oleh ke tiga lembaga tersebut maka pers akan mengontrol lewat pemberitaan dan pada akhirnya publik akan tahu dan ikut berpartisipasi dalam proses keputusan suatu kebijakan lewat diskusi di media. Selanjutnya secara operasional pers harus dapat menghidupi diri sendiri tanpa meminta bantuan kepada pemerintah. Ini diperlukan untuk menghindari tekanan-tekanan dari pihak pemerintah untuk melaksanakan tugas tersebut pers Indonesia mempunyai Undang-Undang (UU) yang dijadikan landasan operasionalnya yaitu UU tentang pers. Hingga sekarang, sudah tiga kali UU tentang pers mengalami revisi, yaitu UU No. 11 Tahun 1966. Kemudian direvisi dengan UU No. 21. Tahun 1982, dan terakhir direvisi dengan munculnya UU. No. 40 Tahun 1999. Disamping itu ada beberapa keputusan menteri dan peraturan pemerintah.

Dalam UU pers (UU. No. 11/1966 maupun UU. No. 21/1982) disebutkan secara jelas fungsi pers di Indonesia. Diantaranya, disebutkan dalam pasal 2 ayat 2 point c, bahwa tugas pers memperjuangkan kebenaran dan keadilan atas dasar kebebasan pers yang bertanggungjawab. Pasal-pasal lainnya juga mengatur aturan pers dalam berinteraksi dengan pihak lain, misalnya tentang penggunaan hak jawab bagi pihak yang dirugikan, tidak dikenal istilah brede/ dan mekanisme yang dilakukan jika pers melakukan pelanggaran.

Jika melihat hal yang demikian, pers Indonesia mempunyai landasan operasional yang memadai. Tetapi jika melihat proses pergantian UU Pers, ada hal menarik. Proses perubahan UU Pers tidak terlepas proses pergantian kepemimpinan nasional yang secara tidak langsung ikut mengubah arah kebijakan politik di Indonesia. Begitu juga dengan hubungan pers dan pemerintah. UU No. 11 Tahun 1966 dibuat pada masa Moch. Syahri, Intervensi Pemerintah Terhadap 
Kebebasan Pers 115 pemerintahan Presiden Sukarno. UU No. 21 Tahun 1982 dibuat pada masa pemerintahan Presiden Soeharto (zaman Orde Baru), dan UU No. 40 Tahun 1999 dibuat pada masa pemerintahan Presiden Habibie. Dari ketiga proses pergantian UU dan kepemimpinan nasional, masa pemerintahan Presiden Soeharto merupakan masa yang menarik bagi perkembangan pers, terutama hubungan pers dan pemerintah.

\section{PROBLEMATIK MAKNA BEBAS DAN MAKNA TANGGUNG JAWAB}

Kebebasan Pers secara subtansif tidak saja dijadikan indikator atau cermin tingkat kebebasan yang dimilki masyarakat yang bersangkutan, namun ia juga merupakan cermin tingkat kematangan dan kedewasaan politik yang telah mereka perjuangkan. Indikator tingkat kematangan dan kedewasaan politik ini oleh sementara kalangan, khususnya oleh mereka yang digolongkan dalam kelompokkelompok yang memegang peranan penting di dalam masyarakat dimana pun, seperti para wartawan, cendikiawan, para professional maupun para politisi. Kelompok-kelompok ini menganggap sangat penting dalam menjamin bergulirnya roda suatu pemerintahan yang demokratis. Tingkat kematangan dan kedewasaan politik, ternyata telah pula mengundang pertentangan dari kekuatan-kekuatan politik yang ada tanpa melihat sistem sosial dan ideologi yang dianutnya. Pertentangan antara kekuatan-kekuatan sosial dan politik yang ada sesungguhnya bermuara pada dua masalah yang esensial dalam kehidupan bernegara, yaitu masalah pembangunan nasional dalam hal ini penetapan kebijakan oleh pemerintah dan masalah kebebasan pers. Kekuatan- kekuatan sosial dan politik tersebut mempertanyakan tentang kadar atau bobot yang harus diberikan kepada upaya penyelenggaraan kekuasaan pemerintahan negara, sedangkan pada sisi yang lain juga dipertanyakan tentang kadar dan bobot yang diperjuangkan untuk memperoleh kebebasan yang layak dimiliki oleh semua anggota masyarakat.

Berdasarkan dua aspek tersebut, pembangunan nasional dan kebebasan pers, terutama ketika memberi tekanan yang berbeda. Artinya bila kita menganggap bahwa salah satu lebih penting dari pada yang lainnya, sudah barang tentu akan mengundang banyak pertanyaan. Hal tersebut telah lama dipersoalkan tidak saja di Indonesia,akan tetapi juga hampir di seluruh negara-negara berkembang, dalam konteks ini, kita menyadari sepenuhnya bahwa dalam penyelenggaraan suatu kekuasaan negara, maka merupakan suatu keharusan yang mutlak bahwa persatuan dan kesatuan nasional merupakan suatu prioritas yang harus dipelihara dan dijaga. Bahkan kalau kita lihat di negara-negara sedang berkembang, hal ini merupakan salah satu tugas utama, yaitu pada sisi lain meningkatkan laju pertumbuhan ekonomi, sedangkan pada sisi lain meningkatkan pertumbuhan kehidupan politik. Kedua ciri khas ini didalam mengembang makna yang dalam, yang tidak bisa dipisahkan dari pengertian stabilitas, pembangunan ekonomi dan efesien. Disini sesungguhnya yang sering kita jumpai, bahwa ketiga pengertian tersebut mampu menggeser prinsip-prinsip kebebasan. Hal ini disebabkan karena pada umumnya sering ada dugaan keras bahwa ciri-ciri kebebasan mempunyai potensi untuk mengganggu stabilitas, bahkan mampu pula mengacaukan 
kehidupan politik dan tak heran pula bila terpaksa harus mengorbankan makna pentingnya efisiensi dalam pembangunan.

Permasalahan yang kita hadapi sekarang ini tidak sekedar hanya menggambarkan suatu pertentangan antara prinsip-prinsip efisiensi berlawan dengan prinsip kebebasaan semata akan tetapi tidak mustahil bahwa dalam masyarakat tradisional seperangkat nilai-nilai telah menjadi acuan untuk pembenaraan dari para penyelenggara kekuasaan negara yang pasti sangat mengagungkan unsur stabilitas, antara stabilitas dan pembangunan ekonomi memang berjalan seiring bahkan saling mendukung pada suatu masa tertentu. Namun akan janggal bila unsur stabilitas dijadikan alasan untuk menutup saluransaluran komunikasi dan tersumbatnya sumber-sumber informasi yang mampu menentukan kadar kebebasaan yang bisa disampaikan kepada masyarakat luas. Dari gambaran seperti ini, kita menyadari bagaimana sesungguhnya posisi pers Indonesia dalam mengantisipasi keadaan yang berat sebelah tersebut.

Ada dua pandangan dalam hal ini: pertama lebih menekankan kepada peran dari para professional yang menganut dan berpihak kepada prinsip-prinsip kebebasaan, sedang pandangan kedua lebih menekan kepada pentingnya unsur stabilitas sebagai indikator dalam mengantisipasi perkembangan atau perubahan yang terjadi. Oleh karena itu sebagai suatu kelompok professional, para wartawan dengan sendirinya pula akan tunduk kepada prinsip-prinsip kebebasaan tadi, akan tetapi bila dilihat dari sisi lain terutama wartawan sebagai insan sosial politik, ia terpaksa harus berjuang untuk mempertahankan eksistensinya melalui sanggahansanggahan filosofisnya agar ruang gerak kebebasaan yang diperjuangkan itu mempunyai makna dalam kenyataan hidupnya.

Berdasarkan uraian di atas, maka focus yang diamati tidak lain adalah masalah hubungan antara pemerintah dan pers serta posisi masyarakat di antaranya hubungan itu tidak jarang menimbulkan distorsi karena masing-masing pihak mencoba mempertahankan posisinya terhadap kepentingan umum.

Menggunakan pendekatan yang dilandasi atas prinsip-prinsip kebebasaan, seperti apa yang diperjuangkan oleh sebagian besar insan pers, maka wartawan Indonesia menyadari sepenuhnya bahwa pada akhirnya beban tanggung jawab politik atas esensi dari arti kepentingan umum itu ternyata harus pula dipikul oleh para penyelenggara pemerintahan negara. Demikian juga keadaannya sikap para kelompok professional cendikiawan maupun para politisi sendiri di sebagian besar negara-negara di dunia ini, berlaku dan bertindak yang sama, batasan atas makna kepentingan umum pada dasarnya hanyalah suatu interpretasi atau penentuan dari sudut pandang professional belaka.

Pemberitaan-pemberitaan dalam media massa yang banyak menyangkut masalah-masalah kesukuan, agama dan ras (sara) pada dasarnya juga tidak lepas dari kepentingan umum. Dan pemberitaan semacam itu akhirnya akan menjadi sajian berita yang memiliki kepekaan politik dan sosial dengan kadar yang tinggi. Dengan demikian bila berita-berita yang semacam ini muncul di media massa dan bila penanganannya didasarkan atas pertimbangan keamanan semata-mata maka sesungguhnya pemecahannya tidaklah terlalu rumit karena penyelesainya cukup dengan menggunakan pertimbangan politik saja. Akan tetapi sesungguhnya 
masalah yang ada tidaklah sesederhana itu, karena apabila kepentingan umum terlibat di dalamnya maka tinjauan dari sudut filosofis maupun analisis secara kontekstual ternyata sangat dibutuhkan.dengan demikian jenis pemberitaan yang bermuatan SARA tidaklah semata-mata hanya masalah keamanan dan ketertiban saja melainkan juga merupakan masalah strategis yang akan memakan waktu lama, hal ini berarti bahwa setiap pemberitaan yang terbuka (trasnparan) dan dapat dipertanggung jawabkan, tidak lain merupakan bagian dari tindakan politik tidak saja akan memperhatikan tetapi juga akan menunjang prinsip-prinsip stabilitas pertumbuhan ekonomi maupun efesiensi. Itu sebabnya pers Indonesia dan pers dimana saja dituntut untuk berani berjuang pada tingkat pemikiran filosofis dan mampu meyakinkan para pelaksana kekuasaan pemerintah negara, bahwa setiap upaya pemantapan suatu keadaan tertentu misalnya masalahmasalah yang peka di mata masyarakat maupun pemerintah, acapkali pers harus mengambil jalan dengan resiko tinggi.

Sikap dan tindakan semacam ini oleh semantara para ahli dipandang sebagai kontribusi pers terhadap setiap pemecahan masalah yang dihadapi oleh pemerintah dimana saja. Tindakan semacam ini pada dasarnya adalah merupakan tugas yang sifatnya simbiosis, artinya antara pemerintah dan pers mengemban fungsi saling membutuhkan. Dilihat dari tugas pers untuk bisa meyakinkan pemerintah maka pada dasarnya pekerjaan ini hanya merupakan sebagian dari tugas pers yang memberi ruang gerak yang lebih luas dalam proses pembangunan nasional pada umumnya.

Pada satu sisi negara-negara yang memiliki pertumbuhan pers yang majemuk ditambah pada sisi lainnya dengan model pemerintahan yang dibentuk atas dasar pusat-pusat kekuatan politik yang hidup dalam masyarakat baik yang didasarkan atas pengelompokkan politik maupun pengelompokan atas dasar kekuatan ekonomi, yang satu dengan yang lain sesungguhnya mempunyai corak yang tidak sama, maka pada umumnya dan acap kali terjadi bahwa kebijakan pemerintah yang diambil hanya menguntungkan salah satu kekuatan tertentu dari pusat-pusat kekuatan yang ada.

Dalam kondisi seperti ini dan apabila hal ini kita cari padanannya secara analogi dalam kehidupan pers yang majemuk itu, maka akan sukar tercapai suatu keselarasan tentang kebijakan pers secara nasional kalaupun terjadi di lapangan implementasinya akan mengundang beragam interpretasi. Situasi seperti ini akan sering mengundang lahirnya perbedaan penilaian luwes dan simpatik sedangkan pada sisi lainnya memberi penilaian sebagai pejabat yang galak dan bersikap apriori.

Akibat lain dari situasi seperti ini dalam tubuh insan pers sendiri muncul jargojargon komunikasi seperti pers berkolusi dengan penguasa artinya pers dianggap sebagai alat penguasa belaka dengan cara "tut wuri" saja sedang pers yang dikategorikan bandel atau pemberani mempunyai konotasi sebagai pers berpihak kepada sifat-sifat adversary.

Pers Pancasila adalah pers yang bebas dan bertanggung jawab. Makna bebas dalam pengertian Pers Pancasila itu adalah khas Indonesia, tidak menganut 
kebebasan yang lahir dari konsep kemerdekaan negatif seperti yang dianut oleh Sistem Komunis Soviet dan Sistem Lebertarian.

Arti bebas oleh Sistem Komunis Soviet adalah bebas dari, yakni bebas dari sarana menyatakan pendapat, kapital, individualisme, borjuasi, dan anarki. Dalam pada itu yang diartikan bebas oleh sistem Libertarian adalah bebas dari pengekangan eksternal.

Pers Pancasila juga tidak menganut kebebasan positif seperti yang dianut oleh sistem Tanggung Jawab Sosial yang lahir dari konsep kemerdekaan positif, yaitu bebas untuk, bebas untuk mencapai tujuan melalui pernyataan pendapat.

Yang dianut oleh Pers Pancasila bukan bebas dari dan bebas untuk, malainkan bebas dan, yaitu bebas dan bertanggung jawab sebagaimana tercantum dalam definisi Pers Pancasila.

Tampak di situ bahwa nilai tanggung jawab dinyatakan secara eksplisit sebagai penekanan untuk dijadikan isyarat bagi setiap wartawan Indonesia bahwa di saat sedang menyusun berita, tanggung jawab harus diingat. Tetapi di antara para wartawan masih ada yang mempertanyakan makna bebas dan bertanggung jawab itu. Dalam hubungan ini pemerintah memberikan penjelasan dengan merujuk kepada Keputusan Dewan Pers No. 79/XIV/1974, Produk lembaga tertinggi dalam kehidupan pers yang beranggotakan unsur-unsur pers sendiri, selain unsur-unsur pemerintah dan masyarakat.

Para wartawan tentunya masih ingat, bahkan mungkin bosan mendengar pedoman tersebut, yang antara lain menegaskan bahwa kebebasan pers di Indonesia ditinjau dari aspek-aspeknya yang mencakup sebagai berikut: idiil pada Pancasila, konstitusioanl pada UUD 1945, dan Tap-tap MPR, strategis pada GBHN, yuridis pada UU Pokok Pers, kemasyarakatan pada tata nilai yang berlaku pada masyarakat Indonesia, dan etis pada norma-norma kode etik profesional.

Dari enam aspek tersebut para wartawan dapat menelaah dua aspek yang sangat erat kaitannya dengan kebebasan dan bertanggung jawab itu, yaitu aspek yuridis dan aspek etis.

Secara yuridis dalam penjelasan UU No. 11/1966 yang diubah menjadi UU No. 4 tahun 1967 dan UU No. 21 Tahun 1982 Tentang Ketentuan-ketentuan Pokok Pers yang ditegaskan sebagai berikut:

'Di dalam Undang-Undang ini dicantumkan Tentang Kebebasan Pers, yang menyatakan dan menegakkan kebenaran dan keadilan yang berhubungan erat dengan keharusan adanya pertanggungjawaban kepada Tuhan Yang Maha Esa. Kepentingan Rakyat dan keselamatan Negara, kelangsungan dan penyelesaian perjuangan nasional hingga terwujudnya ketiga kerangka tujuan perjuangan nasional, moral dan tata susila dan pertanggungjawaban kepada kepribadian bangsa". ${ }^{5}$

Dari penjelasan dalam undang-undang itu tampak kekhasan kebebasan pers di Indonesia, yakin dan bertanggung jawab secara lengkap kepada Tuhan Yang

\footnotetext{
${ }^{5}$ Ibid, hal. 117
} 
Maha Esa, masyarakat, negara, dan perjuangan nasional, yang tidak terdapat dalam sistem pers di mana pun di dunia.

Menghangatnya permasalahan bebas dan bertanggung jawab ini adalah ketika para insan pers mengalami trauma akibat dibatalkannya SIUPP beberapa surat kabar: Sinar Harapan pada bulan Oktober 1986, Prioritas pada bulan Juni 1987 dan Monitor pada bulan Oktober 1990.

Tampaknya kasus Monitor oleh para wartawan tidak dipermasalahkan demikian pula oleh masyarakat akademik dan masyarakat umum karena memang korang tabloid itu sudah amat keterlaluan. Yang dipermasalahkan adalah pembatalan SIUPP Sinar Harapan dan Prioritas, sebab berita yang disiarkan kedua surat kabar itu hanya merupakan perbedaan persepsi terhadap kebijaksanaan pemerintah dan tersinggungnya perasaan pihak yang berwewenang akibat keterampilan wartawan.

Tampaknya para wartawan menginginkan dari pemerintah mengenai makna tanggung jawab tadi rumusan yang konkret, bukannya yang abstrak, yang denotatif, bukannya yang konotatif.

Pemerintah merasa rumusannya sudah jelas dan menganggap pers dan wartawan Indonesia sudah dewasa sehingga tidak perlu diterangkan seperti halnya kepada mereka yang belum dewasa.

Tetapi pernyataan yang hakiki baik bagi insan pers maupun bukan insan pers ialah mengapa menghukum pers dilakukan dengan cara mencabut SIUPP, sehingga yang menjadi korban bukan saja wartawan yang bersangkutan, tetapi seluruh wartawan dan karyawan, apakah tidak ada jenis sanksi lain, jika memang harus dicabut SIUPP-nya, mengapa yang menyatakan salah sehingga dikenakan hukuman itu bukan lembaga yudikatif sebagai unsur Demokrasi Pancasila?

Tindakan pembatalan SIUPP pada dekade 80-an dan awal dekade 90-an sekarang ini dinilai oleh masyarakat pers, masyarakat akademik dan masyarakat umum, bukan oleh lembaga yudikatif, sebagai tindakan yang bertentangan dengan Pancasila dan tidak sejalan dengan pendidikan politik yang digalakkan Orde Baru.

Pada tanggal 12 Juni 1991 beberapa anggota DPR RI dari berbagai fraksi mengadakan dengar pendapat dengan para pemimpin redaksi media cetak untuk membahas berlakunya pembatalan SIUPP. Namun sampai berlangsungnya pemilu 1992, permintaan DPR untuk meninjau kembali kebiasaan membatalkan SIUPP itu tidak pernah mendapat tanggapan nyata dan positif dari lembaga eksekutif.

Tampaknya sesudah pemilihan umum 1992 kehidupan politik dan perubahan sosial di Indonesia akan berpengaruh terhadap kehidupan pers di negeri ini. Jika kita menerawang ke belakang dan meneropong ke depan, sejak diselenggarakannya seminar bertema "Tanggung Jawab Sosial Wartawan Indonesia" di Jakarta pada tanggal 6 Februari 1985, pandangan terhadap pers di Indonesia berubah dari pendekatan dikotomi ke pendekatan trikotomi, maka mulai tahun 1993 tampak akan menjadi pendekatan quadrotomi.

Pada mulanya pers di Indonesia dikaji dengan pendekatan dikotomi, disorot dari dua dimensi, yakni dimensi ideal yang mangacu kepada Pasal 28 UUD 1945 dan dimensi ekonomis komersial yang mengacu kepada Pasal 33 UUD 1945. Sejak seminar itu menunjukkan betapa pentingnya peranan wartawan yang melalui 
lembaga persnya turut berpartisipasi aktif dalam akselerasi pembanguan maka dalam pola pendekatan trikotomi unsur wartawan dimasukkan sebagai variabel. Semakin disadari bahwa secara sistemik-holistik wartawan turut menentukan fungsi pers sebagai lembaga ideal, lembaga ekonomis-komersial, dan lembaga sosial dalam meningkatkan kualitas kehidupan masyarakat.

Sesudah Pemilu 1992, jelasnya mulai awal 1993, pendekatan tampaknya akan berubah lagi menjadi pendekatan quadrotomi, ada variabel lain yang akan diperhitungkan, yaitu kelompok pemuda intelektual, di satu pihak akan menjadi "pressure group", dan di lain pihak akan mendominasi anggota-anggota lembaga legislatif (berdasarkan kampanye semua OPP ketika Pemilu 1992), yang tampaknya akan lebih vokal, kritis, aktif, dan kreatif.

Fenomena timbulnya kelompok penekan yang terdiri dari para kawula muda intelektual, pada sejak tahun 1992 ini tampak semakin tumbuh berkembangnya perkumpulan-perkumpulan dalam bentuk forum diskusi yang aktif menggunakan pers sebagai media penyebaran pemikiran dan aspirasinya. Semakin membengkaknya jumlah kawula muda alumni perguruan tinggi, yang di satu pihak memang menimbulkan peningkatan pengangguran intelektual, tetapi di lain pihak menyebabkan bangsa Indonesia semakin berkualitas yang pada gilirannya semakin kritis.

Di penghujung tahun 1992 yang tampak tanggap adalah Menteri Dalam Negeri Rudini yang menunjukkan sikap yang antipatif. Sikap mendagri terhadap budaya telepon dan kasus penyensoran terhadap Sriwijaya Post, merupakan isyarat akan semakin terbinanya Pers Pancasila yang benar-benar Pers Pancasila sejati yang kita idam-idamkan.

Dalam rangka pembinaan Pers Pancasila itu, kiranya tidak perlu saling menuding siapa yang salah. Apabila pemerintah disalahkan oleh pers mengapa melakukan tindakan preventif, antara lain penyensoran terhadap Sriwijaya Post itu, pers juga ikut salah mengapa redaktur surat kabar yang akan naik cetak seraya meminta paraf sebagai jaminan berita bersangkutan dapat disiarkan.

Jika pemerintah dipersalahkan dalam melakukan tindakan represif membatalkan SIUPP, pers juga salah, antara lain kasus monitor yang menyebarkan berita yang menimbulkan keresahan dan mengganggu ketertiban masyarakat yang tidak bisa dimanfaatkan oleh siapapun.

Jika persnya adalah Pers Pancasila, maka jurnalistiknya pun harus jurnalistik Pancasila, bukan "jazz journalism" yang hanya mengolah berita sensasional, bukan "adversary jounalism" yang senang menentang kebijaksanaan pemerintah, bukan pula "government-say-so journalism" yang hanya memberitakan apa saja yang dikatakan pemerintah, bukan pula "checkbook jounalism" yang untuk memperoleh bahan berita memberi imbalan kepada sumber berita, pun bukan "alcohol journalism" yang tidak menghormati "privacy"seseorang. ${ }^{6}$

\footnotetext{
${ }^{6}$ Ibid, hal. 121
} 


\section{PEMERINTAH SEBAGAI SUMBER BERITA}

Secara ideal, orang memilih peran pers sebagai partner, mitra pemerintah. Di sini, pers berdampingan dengan pemerintah untuk mengemban misi mulia, yakni memberikan penerangan dan pendidikan; pendeknya membangun masyarakat. Mengapa masyarakat harus dibangun? Karena, seperti yang pernah dikemukakan Letjen (purn) Sayidiman Suryohadi-Projo (Kompas, 30 Mei 1999), sebagian besar masyarakat Indonesia masih kurang mandiri. Mereka terbiasa menggantungkan diri pada pihak yang kuat atau berkuasa untuk memperoleh ganjaran atau kemajuan, bukan meraihnya sendiri lewat perbuatan atau prestasi. Padahal, tingkat kemandirian para anggota masyarakat terbukti sangat menentukan dalam setiap aspek kehidupan bangsa.

Menurut Sayidiman, kurangnya sifat mandiri ini merupakan akibat dari sejarah bangsa Indonesia pada masa lalu berupa feodalisme dan penjajahan. "Manusia Indonesia sudah lama dihilangkan kemandiriannya," ujarnya dengan tegas. "Dia tidak boleh berpikir mengenai dirinya, apalagi bertindak untuk memperbaiki nasib, kalau tidak berdasarkan petunjuk yang berkuasa, feodal atau penjajah. ${ }^{7}$

Faktor lain yang mengurangi kemandirian adalah hubungan sosial yang tradisional, yang membiasakan orang untuk bergantung pada pihak yang kuat atau berkuasa. "Mereka menunjukkan sifat mandiri jarang malah dihukum karena yang berkuasa tidak senang kalau ada orang yang tidak bergantung padanya. Akibatnya, prakarsa dan kreativitas, yang hanya bisa lahir dari sikap mandiri, menjadi mandek," katanya. Menurut Sayidiman, mereka yang mempunyai ketergantungan tinggi kepada pemerintah, lebih cenderung menentukan sikap menurut selera yang digantungi sehingga sukar diharapkan keberaniannya untuk mengemukakan hal-hal yang memang perlu diajukan demi kepentingan bersama.

Dalam penerbitan surat kabar mana pun akan ditemukan banyak berita bersumber dari pemerintah melalui berbagai instansi dan personalianya. Frekuensi yang tinggi tentang pemerintah sebagai sumber berita pers ini berlaku di negara dengan sistem sosial politik mana pun, baik di Indonesia, Amerika Serikat, atau Uni Soviet sekalipun. Sama dalam arti banyak berita berasal dari pemerintah.

Berita yang diperoleh kadangkala bukan karena dicari oleh pers, tetapi karena peristiwa itu kadangkala terjadi sendiri. Orang tahu, tidaklah selalu demikian halnya. Sering terjadi, berita dari pemerintah dicari oleh pers. Pers minta wawancara dengan seorang pejabat atau mencari data dari suatu instansi.

Hubungan antara pers dan pemerintah dalam kerangka mencari dan membuat berita, bukanlah hubungan sepihak, melainkan senantiasa timbal-balik antara dua pihak. Ada peranan pemerintah, ada peranan pers. Akan menarik, jika misalnya diteliti dalam proses timbal-balik itu, siapa lebih kuat, siapa mempengaruhi siapa, dan dalam kadar yang bagaimana.

Akhirnya, yang menyusun berita adalah pers. Baik dari bahan yang dikumpulkan atas prakarsa pers maupun bahan yang diperoleh dari keterangan

\footnotetext{
${ }^{7}$ Abrar, Ana Nadhya. 1995, Panduan buat Pers Indonesia. Pustaka Pelajar, Yogyakarta, hal 89
} 
pers, akhirnya menyusun dan penyaji berita terakhir adalah pers. Hal itu tidak berarti bahwa pers senantiasa berada dalam posisi yang paling berpengaruh atau paling memberikan warna. Senantiasa yang terjadi adalah proses interaksi.

Sudah lama pers Indonesia dikritik karena kurang mampu mengungkapkan realitas sosiologis yang sebenarnya tengah berlangsung. Pertimbangan bisnis lebih menonjolkan ketimbang misi politik pers yang meniscayakan pendidikan politik masyarakat. Sikap altruistik pers semakin mengendor. Jika demikian, pers bisa berwajah konservatif. Akibatnya, pers tidak mampu memberikan kontribusi dalam mengembangkan reformasi yang justru dituntut masyarakat. Implikasinya lebih jauh, bisa terjadi kemacetan komunikasi politik antara masyarakat atau rakyat dan pemerintah. Padahal, pada kondisi yang serba transisi dalam segala hal, orang membutuhkan katarsis. Komunikasi saling terbuka, saling mendengarkan dan tidak menganggap dirinya paling benar adalah sikap yang amat penting untuk membangun sistem politik yang ada.

Pemerintah sebagai sumber berita mempunyai posisi, peranan, dan pengaruh, menjadi jelas:

1. Memerintah berarti berkomunikasi, yaitu berkomunikasi antara yang diperintah dan yang memerintah, antara pemerintah dan masyarakat. Komunikasi dalam menyelenggarakan pemerintahan juga berlangsung antara pemerintah dan berbagai lembaga serta instansinya, antara pemerintah dengan lembagalembaga seperti Dewan Perwakilan Rakyat serta lembaga-lembaga tinggi lainnya.

Komunikasi itu dilakukan melalui berbagai cara, antara lain, yang menjadi suatu keperluan bagi semua pihak dalam zaman sekarang, ialah komunikasi melalui media massa dan dengan demikian komunikasi itu menjadi terbuka sifatnya.

Melalui komunikasi terbuka, pemerintah pun menjadi lebih terbuka. Keterbukaan itu menjadi pertanda berlakunya suatu pemerintahan yang demokratis, sebab masyarakat pun menyampaikan pesan dan masuknya secara terbuka pula. Keterbukaan juga berarti kontrol. Jika dalam masyarakat pers, kini maupun dahulu sering diserukan agar ada keterbukaan, maka banyaklah implikasi dari "publisitas" itu.

2. Di samping untuk mencapai proses komunikasi terbuka dalam pemerintahan, maka lalu lintas pesan lewat pers bagi pemerintah juga mempunyai berbagai peranan yang lain. Ada dampak-dampak yang bangkit dari sana. Masyarakat serentak mengetahui apa yang menjadi pesan. Misalnya dalam pengumuman peraturan baru atau harga baru atau kebijakan penting lainnya, pesan itu sampai ke masyarakat secara serentak, cepat, dan seluas-luasnya. Adakalanya, dengan mengumumkan suatu langkah tindakan, pemerintah tidak hanya memerlukan masukan dari masyarakat luas, tetapi juga dari instansiinstansinya sendiri.

Dengan pemberitaan itu, instansi-instansi lain yang berkaitan dengan masalahnya, bahkan semua pihak yang terlibat, sekaligus diberi tahu apa yang menjadi keputusan dan tekad pemerintah, yakni penertiban secara konsekuen dan sungguh-sungguh. 
Pengumuman itu berdampak pula dengan terhimpunnya pendapat masyarakat melalui berbagai lembaga, juru bicara dan pers sendiri. Terjadilah proses pembentukan pendapat umum dan pertumbuhan suatu iklim yang akan menunjang tindak lanjut instruksi tersebut.

Dengan uraian tersebut, jika pejabat atau instansi pemerintah menyampaikan suatu pesan secara terbuka melalui pers, maka berbagai pertimbangan dan tujuan dapat menjadi sandarannya. Sekedar menyampaikan pesan agar diketahui, menyampaikan pesan untuk memancing reaksi, untuk memulai proses permbentukan pendapat umum, untuk peringatan bagi instansi-instansi yang bersangkutan, peringatan bagi masyarakat untuk menetralisir suatu isyu, tetapi juga untuk mengetahui bagaimana reaksi masyarakat, atau yang disebut juga untuk melepas balon percobaan. Peranan terakhir, melepas "balon percobaan," acap kali dipakai dalam hubungan internasional, jika suatu negara ingin mengetahui reaksi negara lain mengenai hal-hal tertentu.

3. Bahwa bobot berita ditentukan oleh berbagai faktor: isi, dampak, suasana, panggung (setting), gaya, dan sumber. Ungkapan, "membuat berita adalah mengangkat suatu kejadian ke atas panggung terbuka." (Panggung terbuka itu berupa koran, majalah, radio, film, dan televisi). Karena diangkat ke atas panggung terbuka, maka suatu kejadian yang tidak diketahui, serentak terbuka. Anehnya, begitu kejadian itu diangkat ke atas panggung, terjadilah dinamikanya sendiri: salah tingkah, dramatis dan sensasi warna-warni! ${ }^{8}$

\section{LOKASI SEBAGAI SUMBER BERITA}

Dalam sistem politik di negeri ini, kekuasaan sentral sesuai dengan konstitusi dan realitas berpusat pada kepresidenan. Perhatikan, betapa seorang menteri setiap kali ingin menyampaikan pesan penting, tidak melakukannya lewat departemen, tetapi melalui panggung kepresidenan, menteri menghadap Presiden, kemudian menjelaskan kepada pers di ruangan Bina Graha atau Istana, apa yang dibicarakannya. ${ }^{9}$

Dampak yang akan diperoleh ialah, bahwa kebijakan, tindakan, dan permasalahan di bidang tugasnya sudah diketahui presiden; secara implisit direstui atau ditunjang. Padahal, pengetahuan apalagi restu dan dukungan Presiden, di samping penting untuk diketahui masyarakat, juga perlu dimaklumi oleh sesama menteri dan instansi, apalagi jika kebijakan atau tindakan itu akan berhubungan dengan kepentingan sesama instansi. Bagaimana pembuatan berita dilihat dari pihak pers. Pers pun mempunyai pertimbangannya sendiri, ketika secara aktif menggali bahan berita dari pemerintah atau pun menerima berita dari pemerintah.

Kekuasaan pemerintah dalam menyelenggarakan pemerintahan dalam arti luas, merasuki seluruh masyarakat sampai ke tingkat terbawah. Tali-temalinya bersifat vertikal maupun horizontal, dan dampak dari kebijakan dan tindakannya pun, besar dalam masyarakat. Jika pemerintah memutuskan kenaikan harga angkutan, misalnya, akibatnya jauh dan luas. Karena itu masyarakat amat

\footnotetext{
${ }^{8}$ Oetama, Jakob, 1987. Perspektif Pers Indonesia. LP3ES, Jakarta, hal. 49

${ }^{9}$ Ibid, hal. 49
} 
berkepentingan untuk mengetahui apa yang menjadi pemikiran, kebijakan, persepsi, dan tindakan pemerintah mengenai semua bidang yang juga menjadi bidang kehidupan masyarakat.

Karena pers berperanan sebagai komunikator, dalam hal ini antara pemerintah dan masyarakat, masuk akal apabila pemerintah menjadi sumber pokok pemberitaan pers. Maka disentra-sentra pengambilan keputusan dan pemerintahan, ditempatkanlah wartawan.

Pada pers pun terdapat beberapa pertimbangan yang menjadi sandarannya dalam mencari berita dari sumber pemerintah.

Pertama, untuk menyampaikan segala pesan pemerintah dan berbagai instansinya, yang patut diketahui masyarakat. Maksudnya agar terjadi komunikasi dalam proses pemerintahan dan terjadi pula penyebaran pengetahuan tentang kebijakan pokok, tindaklanjut, rencana, dan masalah-masalah yang dihadapi oleh pemerintah.

Pemerintah sendiri sering menghargai kecepatan dan keserentakan pers dalam menjalankan peranan tersebut; lebih cepat dan katanya lebih efektif daripada komunikasi lewat nota dinas, instruksi, dan lain-lain. Barangkali memang demikian halnya, sekurang-kurangnya untuk beberapa hal dan untuk beberapa kesempatan.

Ditinjau dari peranannya sebagai komunikator, pers telah berkembang di semua negara, menjadi perangkat yang sama eksistensinya dengan lembagalembaga masyarakat maupun pemerintahan lainnya. Hanya saja hal itu tidak selalu disadari oleh masyarakat pers sendiri; tentu saja dengan segala implikasinya, seperti: tanggung jawab, kualitas profesi, pengembangan perangkat lunak dan keras, serta pengembangan visi agar lebih sanggup menjalankan peranannya.

Kedua, di samping sebagai komunikator umum, dalam menggali berita dari sumber pemerintah, pers mempunyai pertimbangan-pertimbangan lain, yang tidak terlepas dari persepsi pers tentang peranan yang harus dilakukannya.

Beberapa pertimbangan itu antara lain: keperluan untuk mengecek. Pers memperoleh bahan. Untuk melengkapi bahan dan menguji kebenarannya sebelum diterbitkan, maka pers datang kepada instansi yang bersangkutan. Pekerjaan ini tidak senantiasa lancar. Jika bahan berita itu tidak mengandung hal-hal negatif, mungkin instansi yang bersangkutan enggan memberi keterangan, sehingga terjadilah persoalan. Orang tidak dapat begitu saja mengancam instansi itu, termasuk pers, yang juga tidak senang jika kekurangannya diumumkan. Hal itu kecenderungan yang berlaku umum.

Pers kita tidak berani melakukan kontrol terhadap pelaksanaan misi bangsa dan negara yang dipikul pemerintah, karena menganggap kebutuhan dan kepentingan pemerintah senantiasa sama persis dengan kebutuhan dan kepentingan masyarakatnya.

Pers Indonesia sering 'memenggal' berita, kalau dikhawatirkan kelengkapan berita justru dapat merusak stabilitas kepentingan pemerintah. Menurut para ahli, daripada melakukan 'pemenggalan berita' lebih baik berita itu sendiri tidak disiarkan. Sebab, dengan menyiarkan sebagian fakta, apalagi dengan pamrih politik tertentu, justru akan timbul kesan pers telah "membohongi" publiknya. 
Dengan perkataan lain, pers Indonesia dituntut untuk senantiasa berorientasi pada objektivitas pemberitaan. Jika memang objektivitas dimaksud berada pada kubu pemerintah, maka pers kita harus tetap menyatakan demikian. Tetapi kalau sebaliknya yang terjadi, di mana objektivitas berada di kubu masyarakat, maka pers Indonesia tidak perlu takut mengangkatnya ke atas permukaan.

moral obligation pers nasional kita ada manakala pers kita tidak mampu memenuhi kewajiban moral demikian, kelompok itu mengkhawatirkan kalau-kalau pers Indonesia tidak pernah akan mampu menjadi pers masyarakat.

Kewajiban moral pers, di antaranya, untuk menghindarkan 'korupsi berita', hanya karena desakan kepentingan komersial atau politis tertentu. Pers Indonesia yang bersedia mengorbankan kepentingan mengangkat ke atas permukaan sesuatu atau berbagai kebenaran hanya karena tuntutan komersial atau politik tertentu, merupakan gejala awal dari kehancuran moralitasnya.

Baik pemerintah maupun masyarakat kita perlu diberi peluang menuntut hak untuk memperoleh pelayanan pers yang wajar dan benar. Ukuran kewajaran dan kebenaran tersebut bukanlah ukuran subjektif, melainkan ukuran objektif. Dengan ukuran objektif ini, maka publik media massa kita, baik pemerintah maupun masyarakat akan menuntut pers Indonesia menyampaikan informasi yang menyelamatkan kepentingan masing-masing secara menyeluruh, dan yang didasarkan atas kebenaran. Dengan demikian, sekalipun menyangkut kepentingan pemerintah atau kepentingan masyarakat, tapi bila setiap kepentingan pemerintah atau kepentingan masyarakat, tetapi bila setiap kepentingan itu tidak dilandasi oleh jaminan hukum moral itu formal, dalam arti bersifat subjektif, maka pers Indonesia harus berani menentangnya.

Dengan kata lain, setiap pers nasional kita dituntut mau dan mampu 'bersuara keras' terhadap apa-apa yang dilihatnya tidak benar, tidak adil, tidak jujur, tidak bijaksana, dan sejenis lainnya. Apapun resiko dari sikap dan tindakan itu, pers kita harus tetap berani menghadapinya, dalam rangka memantapkan keberadaan pers Indonesia sebagai pers objektif, baik bagi kepentingan pemerintah atau masyarakat.

\section{PERS, PEMERINTAH DAN MASYARAKAT}

Di samping untuk mengecek dan melengkapi, datangnya pers kepada sumber pemerintah itu juga untuk menjalankan peranan kontrolnya. Keterangan dan data yang diperoleh dari pemerintah akan dibandingkan dengan keadaan nyata ataupun data yang diperoleh dari lapangan.

Seperti halnya pemerintah yang mempunyai motif sendiri dalam menyampaikan bahan berita, demikian pula pers. Bagaimana dilakukan akomodasi antara pertimbangan pemerintah dan pertimbangan pers? Atau secara praktis, pertanyaan itu dapat dirumuskan: Bagaimana menyampaikan bahan berita atau pesan pemerintah itu kepada masyarakat? Seperti yang dimaksudkan oleh sumber berita, ataukah seperti yang secara subjektif ingin ditafsirkan oleh pers? ${ }^{10}$

\footnotetext{
${ }^{10}$ Op cit, hal. 52
} 
Setiap hari, menjadi masalah. Masalah yang timbul tidaklah selalu bersifat substansi, seringkali sekedar teknis, tetapi kendala teknis itu dapat menimbulkan akibat yang substansial. Kendala teknis itu, misalnya, terbatasnya ruangan dalam pers atau kemacamragaman isi pers yang harus dijaga, sehingga semua bahan berita pada umumnya harus dipersingkat. Dalam melaporkan keterangan pers atau bahan berita dari pemerintah bahkan juga bagi sumber mana pun, esensi pesan seperti yang diinginkan oleh sumber berita, wajib disampaikan. Apabila pers ingin memberikan tekanannya sendiri atau warnanya sendiri atau versinya sendiri, semua itu tidak boleh meniadakan esensi pesan seperti yang dikehendaki oleh sumber berita. Yang tersangkut di sini bukan sekedar soal pejabat kurang berkenan atau tidak puas, tetapi yang terlibat disini, lambat-laun ialah soal kredibilitas pers. Jika pers terlalu sering salah proporsi berita, lambat-laun kredibilitasnya tergugat.

Sikap itu timbal-balik. Sumber berita termasuk sumber berita pemerintah diandaikan juga dapat memaklumi, bahwa sampai batas tertentu, pers boleh memberikan tekanannya sendiri pada suatu pesan, asal saja visi subjektif itu tidak dimaksudkan untuk mengubah esensi atau meniadakan bagian yang esensial dari suatu pesan.

Contoh-contoh praktis itu dikemukakan untuk secara kongret melukiskan bagaimana terjadinya interaksi antara pemerintah dan pers, kiranya cukuplah uraian praktis ini. Kita beralih ke tataran yang menjadi latar belakang dari hubungan praktis itu. Sebelumnya perlu dikemukakan, bahwa di samping sebagai sumber berita, pemerintah juga sebagai pembaca pers. Pers mempunyai kerisauan yang bersifat umum. Ia ingin agar pesannya sampai, diterima, dimengerti, dan diberi reaksi oleh khalayak pembacanya.

Kerisauan agar pesannya sampai kepada pemerintah, terutama menyangkut berita-berita yang bersumber dari masyarakat. Jadi ada hubungan segi tiga: perspemerintah-masyarakat. Dalam masalah roman, hubungan triangle senantiasa membawa masalah. Apakah demikian dalam interaksi pers, pemerintah, dan masyarakat?

Faktor pemerintah sebagai khalayak pembaca, antara lain berpegaruh dalam gaya pers menyampaikan pesannya kepada pemerintah. Sebab, jika diinginkan agar pesan itu sampai, maka kerangka referensi termasuk juga latar belakang kebudayaan dari lawan bicara atau lawan komunikasi perlu dipertimbangkan. Orang Perancis bilang, yang membuat musik adalah nadanya; artinya yang menentukan dampak pesan adalah gayanya.

\section{INTERAKSI PERS DENGAN PEMERINTAH}

Rumusan Dewan Pers tentang interaksi positif antara pers, pemerintah, dan masyarakat, masuk menjadi keputusan resmi GBHN (Garis-garis Besar Haluan Negara). Mungkin ada yang mencemooh, tetapi kiranya orang tidak dapat mainmain dengan suatu keputusan konstitusional. Lebih arif dan barangkali juga lebih bermanfaat mencoba mencari latar belakangnya dan bagaimana menafsirkannya.

Rumusan itu dibuat setelah peristiwa 1974 yang kemudian dikenal sebagai peristiwa 15 Januari 1974, "Malari." Dalam pergolakan politik itu, sejumlah 
penerbitan menjadi kurban. Timbullah pemikiran di kalangan masyarakat pers yang dirintis oleh Dewan Pers.

Orang sampai pada pemikiran, sesungguhnya bagaimanakah hubungan yang sebaik-baiknya antara pers dan pemerintah. Dalam teori otoriterisme dan teori totaliterisme, pers hanyalah sekedar aparat pemerintah, suatu ekstensi pemerintah, dan karena itu "tunduk" alias untergeornet kepada pemerintah, sehingga dengan sendirinya tiada kebebasan dalam sistem itu. ${ }^{11}$

Dalam teori liberalisme, termasuk liberalisme yang telah mengalami berbagai reformasi seperti keadaannya sekarang di negara-negara industri Barat, pers merupakan lembaga yang otonom, independen, dengan tugas pokok watch dog, penjaga atau pengontrol pemerintah. Semangatnya ditafsirkan sebagai semangat saling curiga dan bermusuhan.

Barangkali ada benarnya bahwa dalam kebudayaan mereka cara menjalankan kontrol itu seringkali disertai ekspresi seakan-akan mereka berada dalam posisi permusuhan. Misalnya karena cenderung memakai bahasa lugas dan kata-kata langsung, jika masalah yang diungkapkan adalah masalah peka. Kecuali soal sistem yang berbeda, dalam pertimbangan ini harus juga dimasukkan faktor adanya kebudayaan yang berbeda.

Masalah pokok bukanlah "bagaimana mereka," tetapi "bagaimana kita." Untuk membuat kontras dengan sistem-sistem lain dikatakan, bahwa hubungan pers dan pemerintah dalam sistem demokrasi Indonesia dewasa ini bukanlah tunduk, tidak juga bermusuhan, tetapi sering disebut partnership, interaksi positif, dan oleh kongres Persatuan Wartawan Indonesia (PWI) di Manado diusulkan untuk diubah menjadi interaksi konstruktif.

Dalam hal ini ada beberapa hal yang perlu diperhatikan di dalam sistem demokrasi Pancasila, apabila kebudayan dan perangkatnya semakin lebih berkembang, tampaknya semangat kekeluargaan dan juga semangat paternalisme dalam tata hubungan pemerintahan Indonesia, hadir dan mempengaruhi tata hubungan antara berbagai lembaganya, termasuk antara pers dan pemerintah.

Pada taraf perkembangannya, yang kuat adalah pemerintah. Sedangkan lembaga-lembaga lain, seperti organisasi politik, perlemen dan pers masih berada dalam taraf perkembangan. Sekalipun pahamnya sering partnership dan paham interaksi, namun dalam kenyatan dan dalam sistem, apalagi dewasa ini, yang terkuat adalah pemerintah. Untuk sebagian besar, keadaan itu merupakan hasil dari perkembangan sejarah di negeri ini dan merupakan suatu keperluan yang timbul dari taraf perkembangan masyarakat, beserta berbagai permasalahan yang dibawanya, dan yang hanya dapat dikendalikan dan dipecahkan, jika ada suatu pemerintahan yang kuat serta periode stabil yang memadai.

Dengan begitu, sama sekali tidak berarti orang lantas buta akan kemungkinan berakumulasinya kekuasaan yang cenderung salah. Pemahaman itu harus ada. Tetapi akan lain halnya jika kerisauan itu disertai suatu pemahaman terhadap seluruh kaitan masalah atau tidak. Dalam sistem politik apapun dan dalam sistem

\footnotetext{
${ }^{11}$ Oetama, Jakob, 1987. Perspektif Pers Indonesia. LP3ES, Jakarta, hal. 55
} 
kebudayaan politik manapun, pemerintahan adalah kekuasaan. Artinya kekuasaan menjadi porsinya yang sah sekaligus juga membawa potensi berbagai kerawanan yang berlaku umum di mana-mana dan dalam sistem apapun.

Sekalipun dalam posisi hubungan baik, hubungan seiring, dan hubungan positif, namun kontrol dan koreksi tetap menjadi salah satu tugas pers yang penting. Dalam daerah kontrol dan koreksi inilah, gangguan interaksi positif terjadi, semua pihak senang dan bergairah, manakala isi pers juga menyangkut yang baik, yang menunjang, yang memuji, yang positif. Persoalan menjadi rawan apabila isi pers juga mengandung kritik, koreksi, kontrol, dan hal-hal yang negatif.

Perlu disepakati bersama, bahwa hubungan pers dan pemerintah dalam sistem Indonesia, memperbolehkan bahkan menganjurkan berlakunya peranan kontrol dan koreksi. Hal itu berarti, pers dapat mengemukakan hal-hal yang benar terjadi dan benar ada, sekalipun tidak enak yang mengandung hal-hal negatif dan menyampaikan kritik serta koreksi. Karena semua orang, termasuk pers tidak senang dikritik apalagi kritik secara terbuka, maka masuk akal bila dalam kawasan ini akan selalu ada persoalan. Adakah jalan untuk mendudukkan persoalan pada proporsinya dan dengan demikian akan mengurangi ketegangan serta kesalahpahaman.

Melalui paham interaksi, sesungguhnya ingin dicoba dikembangkan suatu hubungan antara pers, masyarakat, pemerintah yang cocok dengan keadaan Indonesia. Keadaan di sini tidak boleh ditafsirkan hanya sebagai keadaan yang menguntungkan pemerintah atau yang membatasi kebebasan, melainkan keadaan yang menguntungkan masyarakat, yang membuat tugas pemerintah terhadap kesejahteraan masyarakat lebih tercapai. Interaksi bukanlah dimaksudkan untuk membatasi kebebasan, tetapi untuk mengembangkan suatu kebebasan yang tidak dilepaskan dengan perkembangan masyarakat dan arahnya harus semakin maju.

\section{INTERAKSI PERS DENGAN MASYARAKAT}

Dalam teori maupun praktek, hubungan pers dan pemerintah tidak dapat dilepaskan dari hubungan pers dan masyarakat. Hubungan segi tiga perspemerintah-masyarakat dapat dibedakan, tetapi tidak dapat dipisahkan, dan antara ketiganya terjadi relasi yang saling mempengaruhi. Kadar dan bobot hubungan pers dengan pemerintah dipengaruhi oleh hubungan pers dan masyarakat serta hubungan masyarakat dengan pemerintah.

Dalam perspektif komunikasi, pengertian interaksi merupakan prinsip komunikasi dua arah. Di sini, menunjukkan adanya saling ketergantungan antara komponen-komponen komunikasi untuk mencapai tujuan tertentu. Artinya, pers dalam menjalankan fungsinya tidak terlepas dari komponen lainnya, yaitu pemerintah dan masyarakat. Karena itu, antara ketiga komponen tersebut perlu adanya interaksi yang positif.

Dalam Sidang Pleno XVIII Dewan Pers di Solo 1977, telah diambil keputusan yang menetapkan keperluan "interaksi positif antara pers, pemerintah, dan masyarakat." Interaksi, pada dasarnya, mempunyai pengertian tersendiri. Ia harus dikaitkan dengan perhubungan; komunikasi antara jajaran kaum wartawan yang mengelola pers dan anggota-anggota masyarakat, baik sendiri-sendiri maupun 
dalam hubungan massal. Namun secara universal menurut B. M. Diah, dapat dikatakan bahwa "interaksi ialah hubungan atau komunikasi yang terjadi antara komunikator atau penghubung (communicator) dan orang yang dihubungi (communicant)" (dalam Atmadi, 1985:275). Dalam penilaian Diah, pesoalan ini dalam suatu negara apapun sistem sosialnya menjadi persoalan yang meminta perhatian khusus dari sudut ilmiah, dari sudut hukum dan gerakan perikemanusiaan yang berpangkal pada "hak-hak asasi manusia." ${ }^{\prime 12}$

\section{KESIMPULAN}

Dari uraian di atas dapat ditarik kesimpulan, bahwa:

1. Hubungan pers dan pemerintah adalah hubungan yang dibawa oleh kepentingan bersama untuk menyampaikan dan menerima pesan, untuk menyampaikan dan menerima kontrol sebagai upaya untuk meningkatkan pelayanan kepada kepentingan masyarakat. Perangkat pemerintah sejak dulu menjadi keharusan bagi masyarakat. Perangkat pers meenjadi keharusan untuk masyarakat zaman sekarang dan seterusnya.

2. Hubungan itu berada dalam semangat kerja sama, semangat seiring, semangat kekeluargaan yang menjadi ciri khas masyarakat Indonesia. Kebersamaan itu tidak meniadakan atau mengurangi posisi dan peranan masing-masing. Peranan masing-masing itu, di samping menjadi sumber kreativitas dan saling merangsang, juga menjadi sumber salah paham, perbedaan cara melihat persoalan, ketegangan. Hal itu di satu pihak harus diterima sebagai keadaan yang tidak terhindarkan; sebaliknya, senantiasa dicarikan jalan keluar melalui dialog dan lain-lain.

3. Interaksi positif bukanlah untuk meniadakan atau melemahkan peranan kontrol dan koreksi pers. Interaksi itu mempengaruhi bagaimana kontrol dan koreksi itu dilakukan serta pada proporsi yang bagaimana. Arah interaksi haruslah tidak membatasi, tetapi semakin meluas, sejalan dengan perkembangan masyarakat.

\section{DAFTAR PUSTAKA}

Adinegoro, 1963. Publisistik \& Jurnalistik. Djilid I. Gunung Agung, Jakarta.

Ali, Novel. 1999. Peradaban Komunikasi politik, Potret Manusia Indonesia. PT. Remaja Rosda Karya, Bandung.

Abrar, Ana Nadhya. 1995, Panduan buat Pers Indonesia. Pustaka Pelajar, Yogyakarta.

Adji, Oemar Seno. 1977a. Pers Aspek-Aspek Hukum. Erlangga, Jakarta.

\footnotetext{
${ }^{12}$ Ibid, hal. 272
} 
Adnan, H. Kiagus, 1985a. "Berita Objektif dan Missi Pers, " dalam Atmadi, T. (ed), Bunga Rampai: Catatan Pertumbuhan dan Perkembangan Sistem Pers Indonesia. PT. Pantja Simpati, Jakarta.

Anwar, H. Rosihan. 1996. Wartawan \& Kode Etik Jurnalistik. PT. Jurnalindo Aksara Pustaka dan Gatra, Jakarta. 1990. Perkembangan Delik Pers di Indonesia. Erlangga, Jakarta.

Alfian. 1991. Komunikasi Politik dan Sistem Politik Indonesia. PT. Gramedia Pustaka Utama, Jakarta.

Arifin, H. Anwar. 1988. 'Dari Pers Perjuangan ke Pers Bisnis (1)". Kompas, 26 Februari 1988.

Atmadi, T. 1985b. Sistem Pers Indonesia. PT. Gunung Agung, Jakarta.

. 1987. "Pers Indonesia sebagai Pers Pancasila," Jurnal Komuniksi, Bil 3 1987, Jabatan Komunikasi University Kebangsaan Malaysia, Bangi, Selangor Darul Ehsan.

Effendy, Uchjana, Onong, 2003. Ilmu, Teori \& Filsafat Komunikasi. PT. Citra Aditya Bakti, Bandung.

Kahya, Eko, 2004. Perbandingan Sistem \& Kemerdekaan Pers. Pustaka Bani Quraisy, Bandung.

Nimmo, Dan, 2000. Komunikasi Politik, Khalayak dan Efek. PT. Remaja Rosda Karya, Bandung.

Oetama, Jakob, 1987. Perspektif Pers Indonesia. LP3ES, Jakarta. 